\title{
IAMJ
}

INTERNATIONAL

AYURVEDIC

MEDICAL JOURNAL

Review Article

ISSN: 23205091

Impact Factor: 5.344

\section{MALNOURISHED MOTHERS AND THEIR EFFECT ON FOETAL DEVELOPMENT - AYURVRDIC AND MODERN SCIENCE CONCEPT}

\author{
Swati S. Mohite ${ }^{1}$, Shreya Pandey ${ }^{2}$ \\ ${ }^{1} \mathrm{HOD}$ and Professor at Prasuti Evam Streeroga department, College of Ayurved, Bharati Vidyapeeth Deemed (to \\ be) University, Pune, Maharashtra, India \\ ${ }^{2}$ MS Scholar at Prasuti Evam Streeroga Department, College of Ayurved, Bharati Vidyapeeth Deemed (to be) \\ University, Pune, Maharashtra, India
}

Corresponding Author: shreyapandey.099@gmail.com

\section{https://doi.org/10.46607/iamj3008112020}

(Published online: November 2020)

Open Access

(C) International Ayurvedic Medical Journal, India 2020

Article Received: 30/10/2020 - Peer Reviewed: 14/11/2020 - Accepted for Publication: 23/11/2020

Check for updates

\section{ABSTRACT}

In developing countries one of strongest predators of adverse pregnancy outcome is due to low Body mass index (BMI) during pregnancy. Low BMI in early stage of pregnancy increases the risk of: Intra Uterine Growth Retardation (IUGR), miscarriage, Premature birth, low birth rate, birth asphyxia, anemia and increased perinatal mortality rates, etc. Ayurveda and modern science both have given a detailed regimen and a proper management throughout the pregnancy for better nourishment of mothers and their foetus.

Keywords: malnourished mothers, foetal development, management of malnourished mothers in Ayurveda and modern science.

\section{INTRODUCTION}

"Maternal mother's health is nation's wealth". Maternal nutrition and health are considered as the most important regulators of human foetal growth. Only a healthy mother can give birth to a healthy child. If women's nutritional value is not fulfilled during pregnancy, they are more likely to give birth to weak children resulting in a high infant mortality / morbidity rate and unhealthy adulthood. In studies it has been found that two fifths of pregnant women in India are underweight. ${ }^{1}$ World Health Organisation's Global 
database says, that BMI of a Healthy pregnant women range is 18.5 to 25 , and any pregnant woman having a body mass index less than 18.5 is considered to be an underweight and malnourished. Effect of malnourished mothers increases the risk of gestational anaemia, hypertension, miscarriages and foetal demises during pregnancy, pre-term delivery and maternal mortality. ${ }^{2}$ Effect of low BMI on baby: Preterm infants experience neurological, respiratory, cardiovascular and other problems as the result of premature birth. For newborn, it can cause low birth weight, foetal intrauterine growth retardation that may have long life consequences on new-born development, quality of life and health care costs. Malnutrition also has an adverse effect on the development of the immune system of the new-born.

\section{Aim and Objective}

Aim- To study malnourished mothers and their effect on foetal development by ayurvedic and modern science concept.

\section{Objective-}

1. To study the causes of malnourished mothers.

2. To study the effect of malnourished mothers on foetal development by ayurvedic and modern science view.

\section{Need to Study}

In current scenario low BMI during pregnancy in mothers creates many of the major complications during pregnancy. If nutritional requirement is not enough during pregnancy it can adversely influence intrauterine development and can also cause preterm deliveries resulting in many diseases in baby. Hence it is needed to study the effect of malnourished mothers on fetal development and find solution as early as possible by ayurvedic and modern science.

\section{Material and Methodology}

Information sources and Searches- A search was conducted for malnourished mothers having low BMI and its effect on fetal development. The search strategy used the keywords "pregnancy", "low BMI", "IUGR", preterm delivery. Informative sources were identified from the Google scholar, PubMed, WHO including additional manual research. Based on quality evaluations, the content was summarized and assessed.
For Each research paper we extracted the following information: Title of guideline, author, development institute, example-social organization, year of publication, guideline type, methodological quality and relevant recommendation.

\section{Literature Review}

Ayurvedic Concept of Nutrition (Poshan) during pregnancy

The union of Shukra (sperm) and Artava (ovum) along with the Atma (Soul) inside the Kukshi (Uterus) forms the Garbha (Foetus) ${ }^{3}$. It is well said that when a pregnant woman uses appropriate diet and proper way of living life with normalcy of Shad garbhakara Bhavas (the six factors for conception) influenced by the time factor the foetus grow normally in the mother's womb. ${ }^{4}$ So the nourishment from the mother's womb plays a prime role for the normal growth of the foetus. For a healthy pregnancy it is proven in Ayurveda that rasdhatu (nutritive fluid) is responsible for garbhautpatti (formation of embryo) and garbhaposhana (nourishment of foetus). Whatever ahara (food) is consumed by the mother, it gets converted into rasa (nutritive fluid). This ahar rasa gives nutrition to her own body, for stanautpattistanapushti (Breast for milk production) and to give nutrition to her garbha (foetus). ${ }^{5}$ Rasa dhatu is dravarupa (fluid), Soumya (soft) and aadyadhatu (first tissue). It gives nourishment to uturottar dhatus (further tissues) that is rakt (blood), mansa (muscle tissue), meda (fatty tissue), asthi (bony tissue), majja (nervous system) \& shukra (ovum or sperm) and performs role of jeevana (giving life), lepana (plasters), snehana (oiling or greasing for smoother function), purana (filling the cavities) and garbhautpatti (formation of embryo). Therefore, ahar rasa in garbhini (pregnant woman) helps in garbhaposhan and garbhautpatti preventing Intra Uterine growth retardation and low birth weight. According to charaka, Bruhaniya (enhance growth) and balya gunas (strength giving properties) are responsible for garbhadharana (stability of foetus). Hence, it increases the uterus strength and avert the premature delivery. Therefore, on following garbhini paricharya (life style during pregnancy) given by many acharyas, 
madhurarasa dravays (sweet taste food materials) majorly contributes in increasing garbhaposhana (nourishment of feotus), garbhadharana (stability of foetus)and in accelerating maans (muscle tissue) and meda dhatu (fatty tissue) production in a under nutrition pregnancy ${ }^{6}$

Drugs like-shatavari, yashtimadhu, jeevak, rishibhak, meda, mahameda, shakra, madhuparni, maashparni, mulethi, manuka, etc.

Others ayurvedic factors supporting nutrition:

Dhosha (fault) dhatu nayaya ${ }^{7,8}$

1. Kedar kulya nayaya (irrigation of different fields by water from a canal)- The process of nourishment of tissues can be linked as Dhatus are nourished by ahara ras by specific dhatuvaha strotas (tissue channels) or canal with help of dhatvagni (digestive fire).

2. Khal kapot nyaya (nourishment of dhatus takes place by selection)-

$>$ The selection of individual items of requirement by individual dhatvagnis from ahar rasa which contains all the nutritive principles.

Dosh-dhatu-mala vichar in poshan (concept of dosh, dhatu, waste products of body in nutrition) $)^{9,10}$

Kapha is associated with earth and water elements.
- Kapha accumulate in Medovahi Srotas (fat channels), thus increasing production of fat tissue (Meda Dhatu). Production of these excess fat tissues results in increase in weight

- Rasa dhatu (nutritive fluid)

- Meda dhatu refers to the fatty tissues of the body. It is playing an important role as it helps in the metabolic process. It helps in lubricate and insulate the body. This Dhatu collects the energies and stores it to provide strength to the body.

- Mans Dhatu (muscle tissue) is the muscle tissue which is responsible for the appearance of the body. Besides, it provides covering, maintaining body posture, gives strength. It is also functioning as lepana (plastering or holding).

- Mala (waste materials)- Excretion of malas in an effective way is important for maintaining better health.

\section{Pathya For Garbhini (Benefits for Pregnant} Women): ${ }^{11,12}$

With the deleterious lifestyle of today it is very important to follow a proper diet given by acharyas with the medicinal supplementation for proper results.

\begin{tabular}{|c|c|c|c|}
\hline Months & Dietary component & Dose & Time \& vehicle Per day \\
\hline First month & $\begin{array}{l}\text { Ghee } \\
\text { Milk }\end{array}$ & $\begin{array}{l}20 \mathrm{ml} \\
100 \mathrm{ml}\end{array}$ & Twice or thrice \\
\hline Second month & Milk medicated with $\underline{\text { Madhura drugs (Shatavari) }}$ & $\begin{array}{l}20 \mathrm{ml} \\
100 \mathrm{ml}\end{array}$ & Twice or thrice \\
\hline Third Month & $\begin{array}{l}\text { Milk with, Honey } \\
\text { Ghee, Rice with milk, } \\
\text { Krushara }\end{array}$ & $\begin{array}{l}100 \mathrm{ml} \\
10 \mathrm{ml} \\
20 \mathrm{ml}\end{array}$ & Twice or thrice \\
\hline Fourth month & $\begin{array}{l}\text { Rice (Oryzasativalinaa) } \\
\text { Dadhi(curd) } \\
\text { Navneet (butter) }\end{array}$ & $\begin{array}{l}50 \mathrm{gm} \\
50 \mathrm{gm} \\
50 \mathrm{gm}\end{array}$ & Twice with meals \\
\hline $\begin{array}{l}\text { Fifth } \\
\text { month }\end{array}$ & $\begin{array}{l}\text { Rice Prepared with Milk, Ghee } \\
\text { Mansrasa (Mutton soup) } \\
\text { Gokshur siddha Ghrut }\end{array}$ & $\begin{array}{l}\text { 50gm (Mushtil } \\
\text { Feast) } \\
100 \mathrm{~m}\end{array}$ & $\begin{array}{l}\text { Twice with meals } \\
\text { Twice with meals }\end{array}$ \\
\hline $\begin{array}{l}\text { Sixth } \\
\text { month }\end{array}$ & MudgaYawagu (Phaseolustrilobus) & $\begin{array}{l}50 \mathrm{gm}(\text { Mushtil } \\
\text { Feast) }\end{array}$ & $\begin{array}{l}\text { Twice/day } \\
\text { with meals }\end{array}$ \\
\hline Seventh Month & $\begin{array}{l}\text { Mudga yavagu } \\
\text { Ghee medicated with prithukparnyadi group of drugs. }\end{array}$ & & \\
\hline Eighth Month & $\begin{array}{l}\text { Mudgayawagu. (Phaseolustrilobus). } \\
\text { Rice grual prepared with milk } \backslash \text { mixed with ghee. }\end{array}$ & $\begin{array}{l}50 \mathrm{gms} \\
\text { (Mushti/Feast }\end{array}$ & With meals \\
\hline
\end{tabular}




\begin{tabular}{|l|l|l|l|}
\hline \multirow{2}{*}{ Nineth month } & $\begin{array}{l}\text { Anuvasana Basti of oil medicated with milk and } \\
\text { madhura drugs. }\end{array}$ & \\
& $\begin{array}{l}\text { Mashyavagu (Teramnuslabialis). } \\
\text { Anuvasan basti with oil prepared with the drugs of } \\
\text { madhura group. } \\
\text { Vaginal tampon }\end{array}$ & $\begin{array}{l}\text { Fogm (Mushti/ } \\
\text { Feast) }\end{array}$ & With meals \\
\hline
\end{tabular}

\section{Apathya}

- Abhayng (massage)

- Udvartan (body scrubbing)

- Travel on irregular roads, travel in speeding vehicles

- $\quad$ Sitting on hard and irregular surface.

- Intercourse, smoking, narcotic drugs, wine or sedatives.

- Sleeping in supine position, lest the cord twists around the neck.

- Taking fish or meat in large quantity

- Holding of natural urges

- Excessive exercise.

- Sleeping in day, awakening in night.

- Squatting or any other abnormal hard postures.

Modern science concept of malnourished women and their effect on fetal development: Maternal factors affecting nutririon ${ }^{13}$ -

1. Lack of a nutritious diet in low-income families.

2. Following an unhealthy diet due to lack of knowledge.

3. Loss of appetite due to other health conditions such as chronic infections, depression, anaemia.

4. use of alcohol, drugs or smoking during pregnancy.

5. few diseases like pre-gestational diabetes, gestational diabetes, pulmonary disease, cardiovascular disease, renal disease, hypertension, celiac disease increases the risk of intrauterine growth restriction, blood clotting disorder/disease.

6. Use of certain medications that may interfere with nutrient absorption.

7. Diarrhoea, nausea, and vomiting may also cause malnutrition.

Uteroplacental factors affecting
preeclampsia,
uterine malformations, Placental insufficiency.

Malnourished baby's health is affected in the following ways ${ }^{14}$ :
- It can lead to stillbirth, premature birth.

- It can increase perinatal mortality risk.

- It can lead to neurological, respiratory, intestinal and circulatory complications in the infant.

- It may lead to birth defects and brain damage.

- Maternal under-nutrition can make a child prone to the following health complications, in the long run:

Renal dysfunction.

- He may face cardiovascular issues like hypertension, atherosclerosis, and coronary heart disease.

- Osteoporosis.

- Organ dysfunction of testes, ovaries, brain, heart, liver, and small intestine, etc.

- Maternal malnutrition can also negatively affect mental development and school performance of a child.

Micronutrient deficiency during pregnancy could adversely affect the baby in the following ways ${ }^{15}$ :

$>$ Iodine deficiency can cause - congenital abnormalities, neurological cretinism, mental deficiency, spastic diplegia, myxoedematous cretinism, etc. It can also increase infant mortality risk.

$>$ Low Zinc levels can cause foetal growth retardation and congenital abnormalities.

$>$ Vitamin D deficiency can lead to rickets in the foetus.

$>$ A deficiency of folate can cause neural tube defects in the infant.

$>$ Calcium deficiency can lead to poor foetal skeletal development.

$>$ Low iron levels in the mother's body can cause foetal growth retardation.

\section{DISCUSSION}

Pre-conception counselling, monthly regimen given by various Acharayas, Herbs are useful as a supportive 
therapy together with other supplements under supervision. Eating a balanced diet is an important part of any pregnancy. The best way to improve your diet is by eating a variety of healthy foods. Various vegetables, pulses, spices, cereals, fruits, dry fruits are helpful in nourishment of low BMI mothers and foetal development. Ayurvedic herbs like Shatavari, Yashtimadhu, Jeevak, Rishibhak, Meda, Mahameda, Shakra, Madhuparni, Maashparni, Mulethi, Manuka, etc. are also useful in fetal \& maternal nutrition \& so improves fetal weight with liquor, resulting into good birth weight of neonate, strengthens uterus to carry fetus thus prevents premature labor. They also act as a good Rasayana (rejuvenates), so strengthens the body systems during fetal life. And helps in promotive and restorative activity.

\section{CONCLUSION}

With help of above research papers, we can conclude that Madhurskand Dravayas, Balaya, Brhaniyas Dravayas are effective in nourishment of mother and foetus. Combination of diet, ayurvedic herbs, preconception counselling and meditation can give best result in increasing baby birth weight with liquor and strengthens uterus to carry fetus by preventing premature labor.

\section{REFERENCES}

1. Obesity or Underweight—What is Worse in Pregnancy? By (SumiAgrawal, Department of Obstetrics \& Gynaecology, Pt. J.N.M. Medical College, G-5, AnandVihar, Near Telibandha, Raipur, 492001 Chhattisgarh India) and Abha Singh (Department of Obstetrics \& Gynaecology, Pt. J.N.M. Medical College, E-8, Shankar Nagar, Raipur, Chhattisgarh India).

2. January 2011- Pregnant women with low bmi $(<19)$ by uzmaurooj, asmaansari, armed forces institute of cardiology \& national institute of heart diseases and shehlabaqai, army medical college.

3. Agnivesha, Charaka Samhita, Revised by Charaka and Dridhabala with the Ayurveda Dipika commentary of Chakrapanidatta, Edited by Vaidya Jadavaji Trikamji Acharya, Shareera Sthana 4/5, Chaukhambha Orientalia, Varanasi,2011, p 316

4. Agnivesha, Charaka Samhita, Revised by Charaka and Dridhabala with the Ayurveda Dipika commentary of
Chakrapanidatta, Edited by Vaidya Jadavaji Trikamji Acharya, Shareera Sthana 4/27, Chaukhambha Orientalia, Varanasi,2011, p 321

5. Kashayap Samhita edited by shri satyapal bhishagcharya with hindi commentary vidyotini, reprint edition, choukhamba Sanskrit series, Varanasi, sutra sthan, 1.

6. Charak Samhita, edited by acharya vidyadhar Shukla, ravi dutt Tripathi, volume 1, chaukhamba sanskrita pratishthan, delhi, viman sthan $8 / 139$.

7. 7th ed. Varanasi: Chaukhambha Orientalia; 2002. Dalhanacharya, Commentator. Sushruta Samhita, Sharira Sthana, Shukrashoditashuddhi Shareeropkrama Adhyaya, 2/33. 348. [Google Scholar]

8. Jadavji Trikamji Acharya., editor. 7th ed. Varanasi: Chaukhambha Orientalia; 2002. Sushruta, Sushruta Samhita, Sharira Sthana, Shareerasankhya Vyakaran Shreeropkrama Adhyaya, 5/3. 363. [Google Scholar]

9. Agnivesh charaka sutra $1 / 41$, in $\mathrm{K} R$ Shrikanth MURTHY, charak Samhita, volume 1, reprint edition Varanasi, chaukhambha Orientalia, 2009

10. Sushtra sutra $15 / 3$ in P V Sharma and dalhan commentory along with critical notes, volume 1 , reprint edition Varanasi, chaukhamba Vishwa Bharati 2005.

11. GarbhiniParicharya (Regimen for the pregnant woman) by VaidyaKoppikar. He was a practicing Ayurvedic Physician at Poddar Ayurveda Hospital, Mumbai specializing in Women's health, especially reproductive health.

12. YEAR2015- International Ayurvedic Medical Journal, GARBHINI PARICHARYA AND ITS CLINICAL IMPORTANCE Anjumani Deka, PG Scholar, KaushalyaKhakhlary, Associate Professor, Dept. of PrasutiTantra\&StreeRoga, Govt. Ayurvedic College, Guwahati-14, Assam, India.

13. Dutta D.C, Textbook of Obstetrics, Edited by Hiralal Konar, 7th Edition, Published by New Central Book Agency(P)Ltd., Kolkata,2011

14. Dutta D.C, Textbook of Obstetrics, Edited by Hiralal Konar, 7th Edition, Published by New Central Book Agency(P)Ltd., Kolkata,2011.

15. Dutta D.C, Textbook of Obstetrics, Edited by Hiralal Konar, 7th Edition, Published by New Central Book Agency(P)Ltd., Kolkata,2011

16. National Institute for Health and Clinical Excellence. Improving the health and nutrition of pregnant and breastfeeding mothers and children in low-income households. 2008. [cited 2009, August 22] 
17. Academy for Educational Development. Maternal nutrition during pregnancy and lactation. 2004

18. World Health Organisation. Promoting Optimal Foetal Development: report of a technical consultation. 2006. [cited 2010, May 2].

\section{Source of Support: Nil \\ Conflict of Interest: None Declared}

How to cite this URL: Shreya Pandey \& Swati S: Mohite Malnourished Mothers And Their Effect On Foetal Development - Ayurvrdic And Modern Science Concept. International Ayurvedic Medical Journal \{online\} 2020 \{cited November, 2020 $\quad$ Available from: http://www.iamj.in/posts/images/upload/5147_5152.pdf 